\title{
Bills Favor Mining and Threaten Conservation of Brazilian Merganser (Mergus octosetaceus) at Serra da Canastra National Park, Minas Gerais, Brazil
}

\author{
Bruno Arantes de Andrade Bueno ${ }^{1 *}$, Marcela Riccomi Nunes ${ }^{2} \&$ Celine Melo $^{1}$
}

\author{
${ }^{1}$ Programa de Pós-Graduação em Ecologia e Conservação de Recursos Naturais, \\ Universidade Federal de Uberlândia - UFU, Uberlândia, MG, Brasil \\ ${ }^{2}$ Sistema de Informações Ambientais para o Desenvolvimento Sustentável - Rede SIADES, \\ Faculdade de Saúde Pública - FSP, Universidade de São Paulo - USP, São Paulo, SP, Brasil
}

\begin{abstract}
Serra da Canastra National Park (SCNP) is one of the most important protected areas in the Cerrado biome. Despite its importance to the conservation of rare and endangered species like Brazilian Merganser, two bills were approved in 2010 by Brazil's Chamber of Deputies aiming to reduce SCNP's official boundaries and to transform some of its parts into an Environmental Protection Area (EPA). We evaluated whether such changes would facilitate mining areas to be legally exploited within the park's area, and if those mining areas would represent a threat to Brazilian Merganser populations at SCNP. Results showed that $55 \%$ of the mining areas currently within the National Park will be located within the new EPA, and six hydrographic micro-basins inhabited by Brazilian Merganser could be affected by environmental impacts caused by mineral exploitation in those areas. For these reasons, we recommend the two bills be refused at the Federal Senate.
\end{abstract}

Key words: Threatened Species, Geoprocessing, Hydrographic Basins, Protected Areas, Birds.

\section{Introduction}

The establishment of protected areas is one of the most reliable and widely-used strategies to conserve biodiversity on the planet (Bruner et al. 2001; Chape et al. 2005). Protected areas help defend natural ecosystems from anthropogenic impacts that would otherwise lead to habitat degradation and destruction, often driving populations and species to extinction (Hunter \& Gibbs 2007). In Brazil, the National System of Protected Areas (SNUC, in the Portuguese acronym) defines two major groups of protected areas: strict protection areas (e.g., National Parks and Wildlife Refuges), and sustainable use areas (e.g., Environmental Protection Areas and National Forests). Unlike sustainable use areas, the direct exploration of natural resources for commerce or consumption is prohibited on strict protection areas, whose fundamental purpose is to preserve nature (Brasil 2000). Despite their legal status and importance to biodiversity conservation, it is not uncommon to find conflicting anthropogenic activities - especially the exploration of mineral resources - being developed within strict protection

*Send correspondence to: Bruno Arantes de Andrade Bueno Programa de Pós-Graduação em Ecologia e Conservação de Recursos Naturais, Instituto de Biologia,

Universidade Federal de Uberlândia - UFU, CEP 38400-902,

Campus Umuarama, Uberlândia, MG, Brasil

e-mail: barantes@gmail.com areas or in their buffer zones (ISA 2006). The exploration of mineral resources is known to cause significant impacts to natural landscapes, their biodiversity and ecosystems, through deforestation, sedimentation and burial of water streams, and increased water and air pollution (Phillips 2001; Palmer et al. 2010).

One important strict protected area in Brazil is the Serra da Canastra National Park (SCNP), which shelters important plants and animals of the Cerrado biome, including endemic, rare, and threatened species (Romero \& Nakajima 1999; Silva \& Silveira 2006). An important bird species that inhabits SCNP is the Brazilian Merganser (Mergus octosetaceus), a rare and Critically-Endangered waterfowl (IUCN 2011). The Brazilian Merganser is extremely sensitive to the degradation of its natural habitat, which is composed of rivers and streams of clean and clear waters, usually surrounded by riparian forests (Hughes et al. 2006; Silveira \& Bartmman 2001). Such habitat characteristics are claimed to be essential for this species' survival (Hughes et al. 2006). SCNP and its surroundings shelter this species' largest currently-known population, with more than 80 individuals (Lamas 2006).

Despite that, two bills were presented to the Chamber of Deputies in 2007 aiming to change SCNP's boundaries: bill $n^{\circ} 1448 / 2007$ reduces its area to roughly 150,000 ha 
(Melles et al. 2007a), and bill $n^{\circ} 1517 / 2007$ transforms the 48,000 ha removed from the park into an Environmental Protection Area (EPA) composed by a mosaic of nine distinct patches (Melles et al. 2007b). According to SNUC, EPA is a protected area category that allows the sustainable economical exploitation of natural resources within its boundaries (Brasil 2000). In practice, transforming parts of SCNP into an EPA may allow environmentally-risky activities such as mining to be legally carried out in spite of their potential environmental impacts. Both bills were approved in late 2010 and are now waiting approval at the Federal Senate, where they may still be altered or refused by its members.

In this study, we used geoprocessing resources to: identify all mining areas within SCNP's official boundaries and on Brazilian Merganser territories; inspect the new boundaries of the National Park and of its associated EPA as defined by bills 1448/2007 and 1517/2007; and evaluate potential impacts of the new park boundaries to conservation of Brazilian Merganser populations.

\section{Material and Methods}

\section{Study area and geoprocessing resources}

The SCNP was created in 1972 with the goal of protecting the headwaters of the São Francisco and Paraná rivers (Silva \& Silveira 2006). Though its official area encompasses almost 198,000 ha, in practice only about 72,000 ha were expropriated and demarcated by environmental authorities. Despite being officially part of the National Park, the remaining area was never incorporated into the park and continued to host human activities like farming, eco-tourism, and mining. In this study, we adopted SCNP's original boundaries defined in the ordinance that officially created it in 1972 (Brasil 1972). All geoprocessing analyses were performed using the software ArcGIS 9.2 (ESRI 2008).

\section{Mining holdings}

Mining holdings are legal permits that authorize the research and exploration of mineral substances in a defined area. In Brazil, the National Department of Mineral Production (DNPM, in Portuguese acronym) is the official body of the Mines and Energy Ministry responsible for granting mining holdings for interested individuals and companies.

We used the shape files provided by DNPM (Brasil 2010) to identify all mining holdings granted until the year 2010 that were completely located within SCNP's official boundaries.

We used Brazilian Merganser occurrence records in SCNP's region (Lamas 2006) to plot the species' territories on a map. We considered $12 \mathrm{~km}$ as the maximum extent of each territory along watercourses (Silveira \& Bartmman 2001), and grouped the identified territories into hydrographic micro-basins using level-6 Otto-basins (ANEEL 2010) so that we could use those basins as study units. We chose to use micro-basins as study units because impacts on aquatic environment of a given stream have the potential to affect other rivers downstream (Palmer et al. 2010), thus putting at risk Brazilian Merganser groups not located on the directly-affected stream but which inhabit the same micro-basin. Therefore, we identified mining holdings that intersected Brazilian Mergansers' micro-basins to assess whether mining could be a threat to habitat integrity at those regions.

\section{Bills 1448/2007 and 1517/2007}

We created maps for both SCNP's and EPA's new boundaries based on their geographical coordinates defined by bills 1448/2007 (Melles et al. 2007a) and 1517/2007 (Melles et al. 2007b). We identified the mining holdings that had centroids either within the EPA or within the remainder of National Park to verify their final distribution among the two categories of protected areas. Mining areas located on EPA patches could be legally exploited and thus would have greater potential to cause environmental impacts.

\section{Results}

\section{Mining holdings within Serra da Canastra National Park}

We identified 105 mining patches (area $=33,339$ ha) located completely within SCNP's official boundaries (Figure 1a). All patches were granted by DNPM between years 1981 and 2010. Five distinct minerals were found to be the object of those grants: industrial diamond $(n=53)$, quartzite $(\mathrm{n}=47)$, diamond $(\mathrm{n}=2)$, quartz $(\mathrm{n}=2)$, and gold ore $(n=1)$. Industrial diamond patches also spanned the largest area (29,409 ha), followed by quartzite (2,843 ha), quartz (775 ha), gold ore (214 ha), and diamond (99 ha).

\section{Mining patches on Brazilian Merganser territories}

We identified 11 micro-basins that encompass territories of Brazilian Merganser at SCNP. Sixty percent $(n=63)$ of the 105 mining areas within the park were partially or completely located within 6 of the 11 micro-basins (Figure 1b). Total area covered by those patches was 30,118 ha, with industrial diamond grants encompassing a total area of 28,011 ha $(\mathrm{n}=51)$, followed by quartzite $(1,020$ ha, $\mathrm{n}=7)$, quartz (775 ha, $\mathrm{n}=2$ ), gold ore (214 ha, $\mathrm{n}=1$ ), and diamond (99 ha, $\mathrm{n}=2$ ) (Figure 2).

\section{Bills 1448/2010 and 1517/2007}

Figure 3a shows both SCNP and EPA as defined by bills $1448 / 2007$ and $1517 / 2007$. Under that new scenario with the park divided into two distinct protected areas, we found 

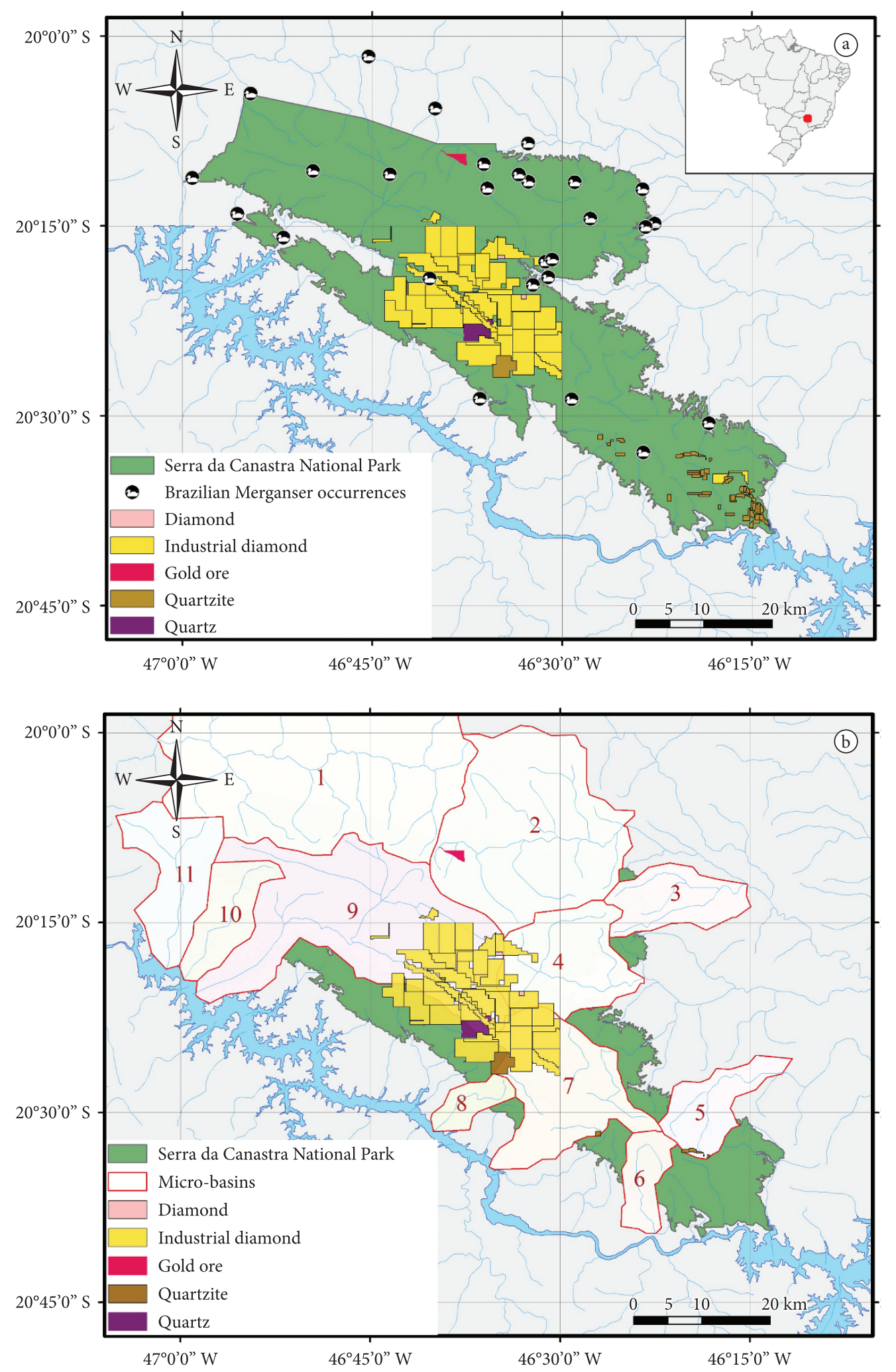

Figure 1. a) Mining areas completely within SCNP's official boundaries, and Brazilian Merganser occurrence records used in this study; b) Micro-basins (numbered from 1 to 11) hosting Brazilian Merganser territories, and the mining areas that intersected the micro-basins. 


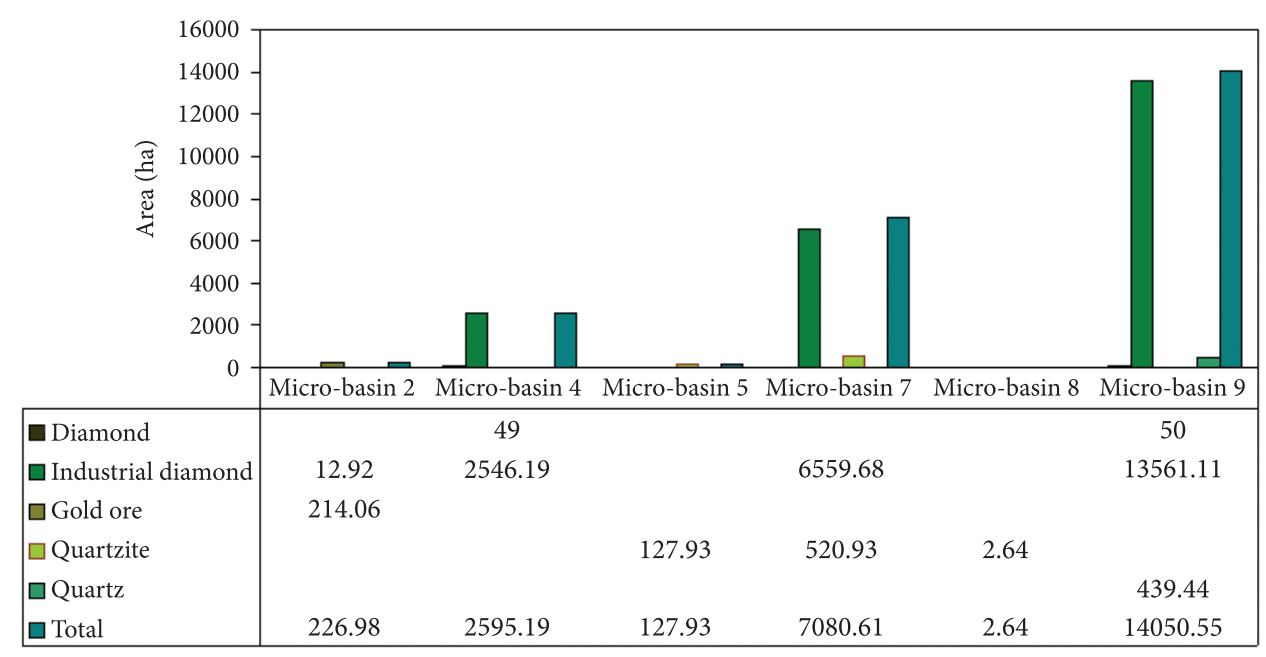

Figure 2. Breakdown of area encompassed by each mineral substance per micro-basin. Micro-basin \#7 had $23.7 \%$ of its area covered with mining patches, followed by micro-basin \#9 (21.9\%), \#4 (11.1\%), \#5 (1.1\%), \#2 (0.4\%), and \#8 (0.1\%).

47 mining areas that had centroids located within the newly delimited SCNP, and 58 that had centroids within the new EPA (Figure 3b). Of those within the EPA, 39 were assigned to quartzite exploitation, 16 to industrial diamond, two to diamond, and one to quartz.

\section{Discussion}

We were able to identify 105 areas inside SCNP's official boundaries that were granted by the National Department of Mineral Production for exploration of five distinct mineral substances. This demonstrates that activities incompatible with the conservation purposes of a National Park are a common reality in SCNP. The government itself seems to have ignored the existence of that protected area: the park has existed for almost 40 years, and for the last 30 , mining access has been granted, regardless of the strict protection category of this site. Unfortunately the SCNP is not an isolated case, in January 2006 there were more than 6,000 mining holdings within federal and state protected areas in the Legal Amazon (ISA 2006). Up to 54\% of the "Serra da Cutia" National Park (southwestern state of Rondônia) was found to be covered with mining holdings (ISA 2006). On SCNP, the mining patches that we found covered $16.8 \%$ of the park's official area; their location on higher elevations, however, increase the amplitude of their potential impacts on watercourses and valleys (Phillips 2001; Palmer et al. 2010). Whereas deforestation and loss of biodiversity are among the most important concerns on protected areas in the Amazon, on SCNP the protection of water resources is of vital importance: the headwaters of two of Brazil's largest hydrographic basins (Paraná and São Francisco rivers) are within the park's area and constitute the main reasons why the park was originally created (Silva \& Silveira 2006).
Besides being illegal according to SNUC's regulations (ISA 2006), the presence of mines within SCNP is a major threat to the Brazilian Merganser survival within the park. Areas of quartzite extraction found on micro-basins of creeks Grande (\#7) and Picada (\#5) put Brazilian Merganser populations at those two micro-basins at risk (Figure 1b). Quartzite extraction is made using explosives, leading to serious environmental damage (Ramirio et al. 2008). Those damages reduce Brazilian Merganser's habitat suitability due to increased sediment load in water and due to destruction of nest and shelter sites (Hughes et al. 2006). The amount of waste produced during quartzite production can reach up to $92 \%$ of the extracted material (Ramirio et al. 2008). Inadequate disposal of such waste can cause suppression of native vegetation and increase silting of streams (see Lamas 2006).

Another worrisome scenario was revealed in microbasins \#9, \#4, and again \#7. Taken together, those three micro-basins contained the largest number of Brazilian Merganser occurrence records $(n=10)$. However, those three regions also contained the largest area granted to mining (23,726 ha), with $96 \%$ of its holdings granted to industrial diamond exploitation (Figure 2). Local extinction of Brazilian Merganser in those micro-basins due to mining impacts could increase its metapopulation vulnerability, leading to a significant damage to the biodiversity SCNP is designed to protect.

By reducing and transforming parts of SCNP into an EPA, bills $1448 / 2007$ and $1517 / 2007$ leave open the possibility that 58 mining areas could be legally exploited (Figure $3 \mathrm{~b}$ ), in spite of all negative environmental impacts they could cause. Among the areas that could be legally exploited within the EPA are those of quartzite production on micro-basin \#5, and diamond mine "DNPM 831719/1990" 

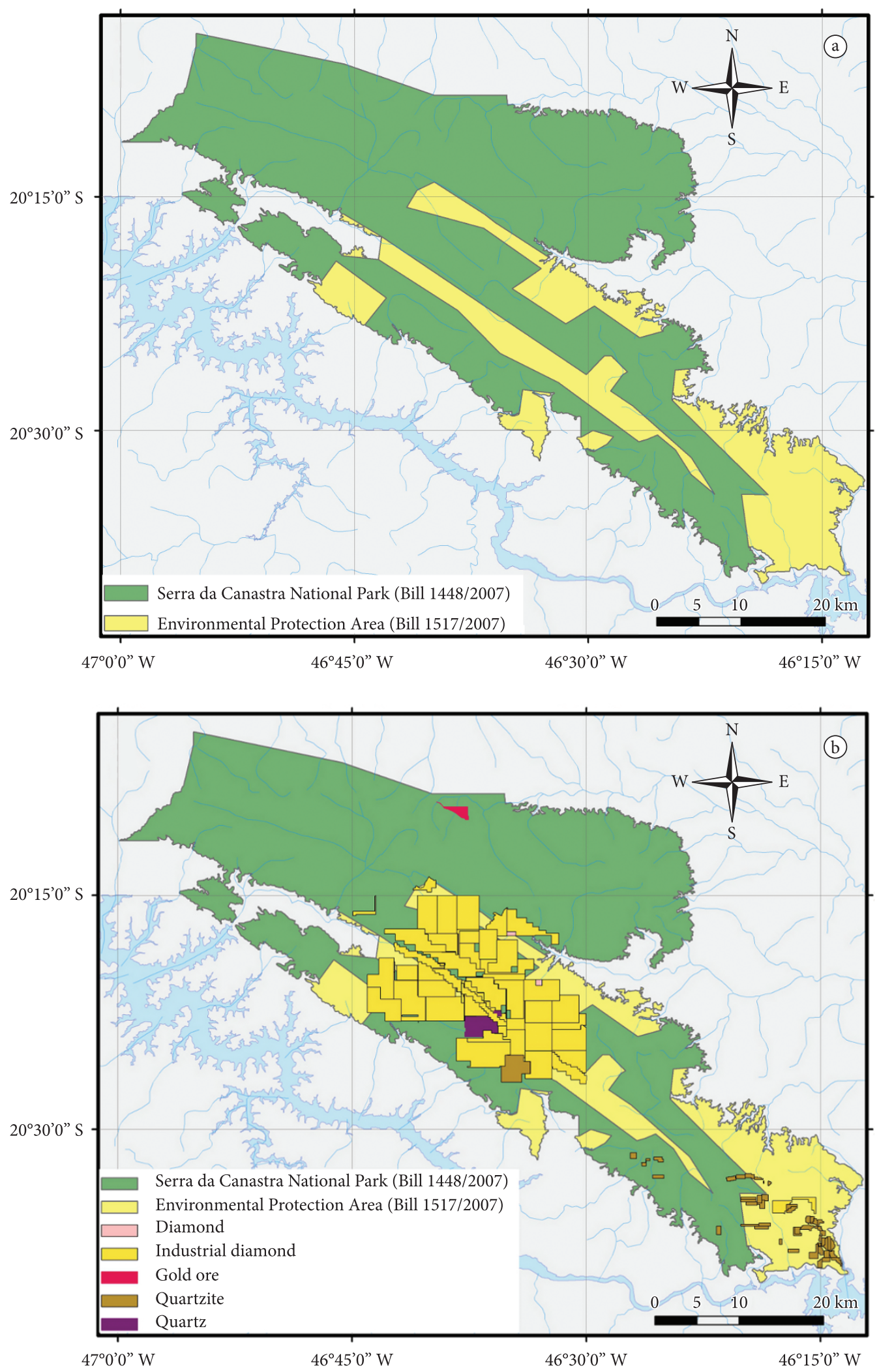

Figure 3. a) SCNP's new boundaries and its patches transformed into EPA as defined by bills 1448/2007 and 1517/2007; b) Mining areas superimposed on new park boundaries, evidencing those previously within SCNP's protected area that will be on EPA. 


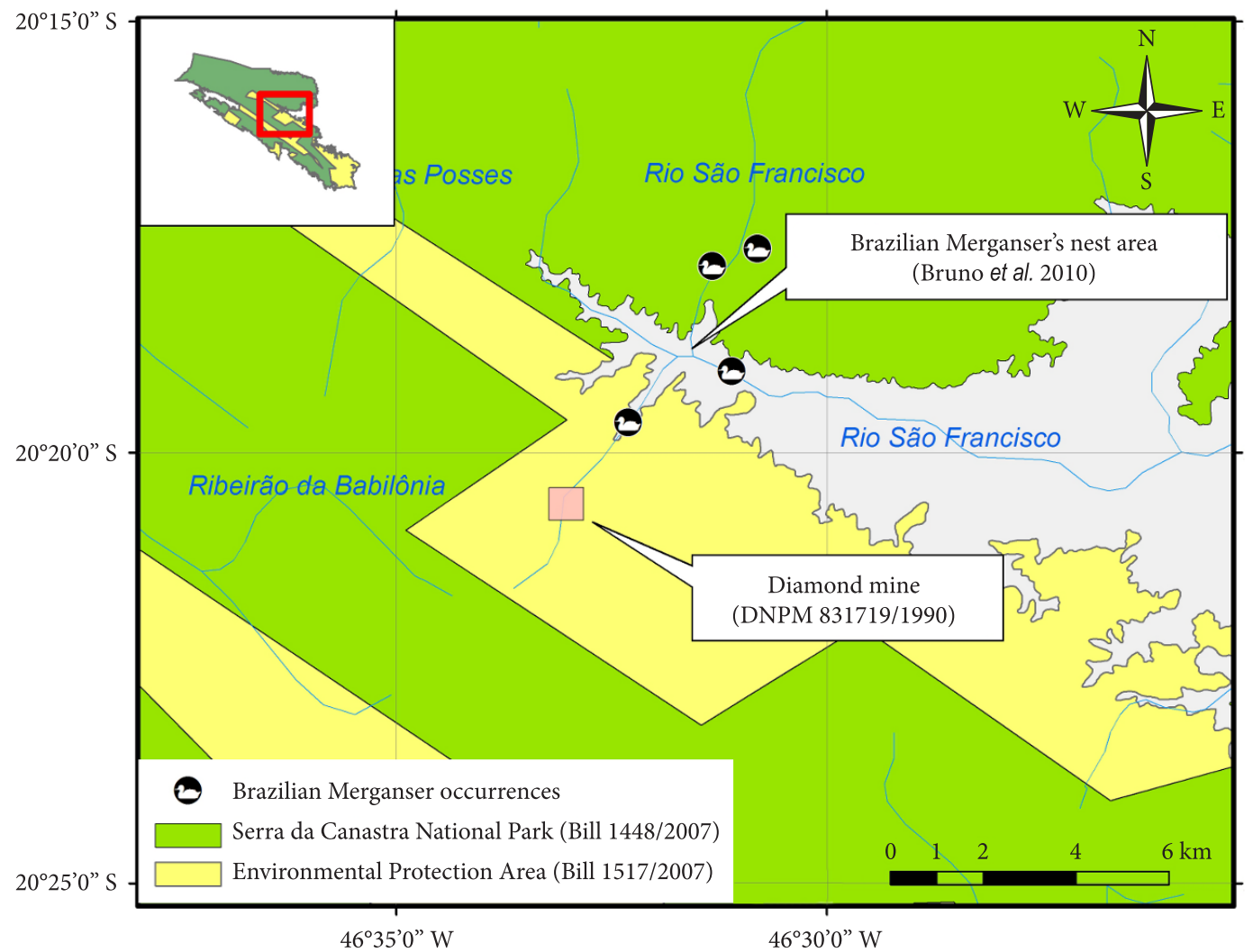

Figure 4. Location of diamond mine "DNPM 831719/1990" for exploration of the Canastra-1 kimberlite. This mine was built on the river São Francisco's headwaters' micro-basin, near important Brazilian Merganser territories. Originally located within SCNP's protected area, this mine will be located within the EPA defined by bill 1517/2007. Note the straight lines and rough angles that define the EPA's boundaries.

on micro-basin \#4 (river São Francisco). The location of this diamond mine on the EPA is of high concern, since it was built over Cachoeirinha creek, a tributary of the São Francisco's headwaters, only $2 \mathrm{~km}$ upstream from a Brazilian Merganser occurrence record and only $5 \mathrm{~km}$ upstream of the São Francisco river (Figure 4). That site is known to be used by Brazilian Merganser for nesting (Bruno et al. 2010).

In addition to its location, what brought our attention to this diamond mine was the fact that it was built to explore the first economically-viable source of primary diamonds in Brazil, the Canastra-1 kimberlite (Chaves et al. 2008). Diamond extraction from primary sources like the Canastra-1 kimberlite is made by digging deep holes to remove soil and process its diamond content. Roughly 2.3 million tons of soil were removed during this mine's experimental phase, and the average size of diamond encountered there was 16 carats (3.2 g) for each 100 tons of rock (Chaves et al. 2008). Exploitation of this kimberlite is predicted to produce from 550,000 to 2 million carats ( 110 to $400 \mathrm{~kg}$ ), during a life period ranging from 5 to 8 years (Brasil 2006). Based on the levels of diamond found during its experimental phase, economic exploitation of this mine could lead to removal of up to 12.5 million tons of soil. As in the case of quartzite, processes of production and waste disposal of kimberlite exploitation represent serious threats to Brazilian Merganser populations. Allowing such activities to take place on the São Francisco's headwaters' micro-basin might eventually lead to local extinction of Brazilian Merganser in that region of SCNP.

Another criticism against bills 1448/2007 and 1517/2007 lies on the fact that the EPA patches they specify are often defined by straight lines and rough angles that do not follow natural landscape features such as rivers or hillsides (Figures 3 and 4). That seems to suggest that the new boundaries specified by those bills have been stipulated without sound technical and scientific criteria, probably just seeking to remove conflicting enterprises from SCNP's protection area.

\section{Concluding remarks}

Transformation of SCNP patches into EPA, as proposed by bills $1448 / 2007$ and $1517 / 2007$, is a political ploy to get around the legal conflicts of the existence of mining holdings within that National Park. Such strategy, however, constitutes a 
major threat to Brazilian Merganser conservation. Therefore, we recommend these bills to be refused at the Federal Senate. Analysis of new park boundaries indicated those bills did not take into account the potential consequences to the ecological attributes that make SCNP the most important natural refuge for rare and endangered species like the Brazilian Merganser. Instead, their intention seems to prioritize the unsustainable exploitation of mineral resources at the expense of biodiversity conservation. Though activities like mining can be financially attractive for corporations and local governments, the economic development they produce is ephemeral. That contrasts directly with the environmental impacts they might cause, which can endure centuries on the landscape. Moreover, such economical wealth is often not shared properly with local communities. Mining companies at SCNP's region are known to subject their workers to unhealthy conditions and to disobey labor regulations (Brasil 2006).

We believe there are alternative ways to reconcile economic development with environmental conservation at SCNP's region. One such alternative is the development of low-impact forms of eco-tourism like birdwatching. In addition to being sustainable and to generate more equally-shared profits, well-driven eco-tourism practices have potential to convert local communities into important partners in the conservation of threatened species like Brazilian Merganser.

\section{Acknowledgements}

We appreciate the improvements in English usage made by Phil Stouffer through the Association of Field Ornithologists' program of editorial assistance, and the valuable suggestions made by Dr. Daniel Brito and anonymous reviewers about this manuscript.

\section{References}

Agência Nacional de Energia Elétrica - ANEEL, 2010. Sistema de informações georreferenciadas do setor elétrico - SIGEL. Available from: <http://www.aneel.gov.br>. Access in: 13 july 2010.

Brasil, 1972. Decreto $\mathrm{n}^{\circ} 70.355$, de 3 de abril de 1972. Cria o Parque Nacional da Serra da Canastra, no Estado de Minas Gerais, com os limites que especifica, e dá outras providências. Diário Oficial da República Federativa do Brasil, Brasília (1972 abr. 4).

Brasil, 2000. Lei n 9.985, de 18 de julho de 2000. Regulamenta o art. 225, $\$ 1^{\circ}$, incisos I, II, III e VII da Constituição Federal, institui o Sistema Nacional de Unidades de Conservação da Natureza - SNUC, e dá outras providências. Diário Oficial da República Federativa do Brasil, Brasília (2000 jul. 19).

Brasil, 2006. Relatório do Grupo de Trabalho Interministerial instituído pelo decreto de 24 de janeiro de 2006, relativo ao Parque Nacional da Serra da Canastra. Brasília. Available from: <http://www.planalto.gov.br/casacivil/arquivospdf/ SERRA_CANASTRA.pdf $>$. Access in: 13 nov. 2010.
Brasil. Ministério de Minas e Energia. Departamento Nacional de Produção Mineral - DNPM, 2010. Sistema de Informações Geográficas da Mineração - SIGMINE. Available from: $<$ http://sigmine.dnpm.gov.br>. Access in: 13 july. 2010.

Bruner AG et al., 2001. Effectiveness of Parks in Protecting Tropical Biodiversity. Science, 291:125-128. PMid:11141563. http://dx.doi.org/10.1126/science.291.5501.125

Bruno SF et al., 2010. Breeding behaviour of Brazilian Merganser Mergus octosetaceus, with a tree-cavity nest in Serra da Canastra National Park, Minas Gerais, Brazil. Cotinga, 32:27-33.

Chape $S$ et al., 2005. Measuring the Extent and Effectiveness of Protected Areas as an Indicator for Meeting Global Biodiversity Targets. Philosophical Transactions of the Royal Society B: Biological Sciences, 360:443-455.

Chaves MLSC, 2008. Província diamantífera da Serra da Canastra e o kimberlito Canastra-1: primeira fonte primária de diamantes economicamente viável do país. Geociências, 27:299-317.

Environmental Systems Research Institute - ESRI, 2008. ArcGIS 9.2. California: Redlands.

Hughes B et al., 2006. Plano de ação para a conservação do pato-mergulhão. Brasília: IBAMA.

Hunter ML \& Gibbs JP, 2007. Fundamentals of conservation biology. Malden: Blackwell Publishing Ltd.

International Union for Conservation of Nature - IUCN, 2010. IUCN Red List of Threatened Species. version 2011.1. Available from: <http://www.iucnredlist.org > . Access in: 24 july 2010.

Instituto Socioambiental - ISA, 2006. Mineração em Unidades de Conservação na Amazônia Brasileira. São Paulo: Instituto Socioambiental.

Lamas IR, 2006. Census of Brazilian Merganser Mergus octosetaceus in the region of Serra da Canastra National Park, Brazil, with discussion of its threats and conservation. Bird Conservation International, 16:145-154. http://dx.doi.org/10.1017/S0959270906000220

Melles C et al., 2007a. Projeto de lei $n^{\circ} 1.448$ de 2007: altera os limites do Parque Nacional da Serra da Canastra, que passa a compor o mosaico de unidades de conservação da Serra da Canastra, nos termos do art. 26 da Lei no 9.985, de 18 de julho de 2000. Available from: <http://www.camara. gov.br/sileg/integras/476410.pdf>. Access in: 6 apr 2011.

Melles C et al., 2007b. Projeto de lei n 1.517 de 2007: cria a Área de Proteção Ambiental da Serra da Canastra, que passa a compor o mosaico de unidades de conservação da Serra da Canastra, nos termos do art. 26 da Lei no 9.985, de 18 de julho de 2000. Available from: <http://www.camara. gov.br/sileg/integras/479655.pdf>. Access in: 6 apr 2011.

Palmer et al., 2010. Mountaintop Mining Consequences. Science, 327:148-149. PMid:20056876. http://dx.doi. org/10.1126/science.1180543

Phillips A, 2001. Mining and protected areas. Geneva: World Business Council for Sustainable Development. Report commissioned by the Mining, Minerals and Sustainable Development project of the International Institute for Environment and Development. Available from: $<$ http://pubs.iied.org/G00554.html>. Access in: 24 mar. 2012. 
Ramirio RF et al., 2008. Estudo comparativo de rejeitos de quartzito com outros agregados comercialmente utilizados como materiais de construção no Sudoeste de Minas Gerais. Ciência et Praxis, 1:25-32.

Romero R \& Nakajima JN, 1999. Espécies endêmicas do Parque Nacional da Serra da Canastra, Minas Gerais. Revista Brasileira de Botânica, 22:259-265.
Silva RS \& Silveira LF, 2006. Serra da Canastra: tesouros naturais do Brasil. São Paulo: DBA Artes Gráficas.

Silveira LF \& Bartmann WD, 2001. Natural history and conservation of Brazilian Merganser Mergus octosetaceus at Serra da Canastra National Park, Minas Gerais, Brazil. Bird Conservation International, 11:287-300. http://dx.doi. org/10.1017/S0959270901000338

Received: October 2011

First Decision: April 2012

Accepted: April 2012 